\title{
Compiling geophysical and geological information into a 3-D model of the glacially-affected island of Föhr
}

\author{
T. Burschil ${ }^{1}$, W. Scheer ${ }^{2}$, R. Kirsch ${ }^{2}$, and H. Wiederhold ${ }^{1}$ \\ ${ }^{1}$ Leibniz Institute for Applied Geophysics LIAG, Hannover, Germany \\ ${ }^{2}$ State Agency for Agriculture, Environment and Rural Areas of the Federal State Schleswig-Holstein LLUR, \\ Geological Survey, Flintbek, Germany
}

Correspondence to: T. Burschil (thomas.burschil@liag-hannover.de)

Received: 11 April 2012 - Published in Hydrol. Earth Syst. Sci. Discuss.: 19 April 2012

Revised: 31 August 2012 - Accepted: 3 September 2012 - Published: 1 October 2012

\begin{abstract}
Within the scope of climatic change and associated sea level rise, coastal aquifers are endangered and are becoming more a focus of research to ensure the future water supply in coastal areas. For groundwater modelling a good understanding of the geological/hydrogeological situation and the aquifer behavior is necessary. In preparation of groundwater modelling and assessment of climate change impacts on coastal water resources, we setup a geological/hydrogeological model for the North Sea Island of Föhr.

Data from different geophysical methods applied from the air, the surface and in boreholes contribute to the 3-D model, e.g. airborne electromagnetics (SkyTEM) for spatial mapping the resistivity of the entire island, seismic reflections for detailed cross-sections in the groundwater catchment area, and geophysical borehole logging for calibration of these measurements. An iterative and integrated evaluation of the results from the different geophysical methods contributes to reliable data as input for the 3-D model covering the whole island and not just the well fields.

The complex subsurface structure of the island is revealed. The local waterworks use a freshwater body embedded in saline groundwater. Several glaciations reordered the youngest Tertiary and Quaternary sediments by glaciotectonic thrust faulting, as well as incision and refill of glacial valleys. Both subsurface structures have a strong impact on the distribution of freshwater-bearing aquifers. A digital geological 3-D model reproduces the hydrogeological structure of the island as a base for a groundwater model. In the course of the data interpretation, we deliver a basis for rock identification.
\end{abstract}

We demonstrate that geophysical investigation provide petrophysical parameters and improve the understanding of the subsurface and the groundwater system. The main benefit of our work is that the successful combination of electromagnetic, seismic and borehole data reveals the complex geology of a glacially-affected island. A sound understanding of the subsurface structure and the compilation of a 3-D model is imperative and the basis for a groundwater flow model to predict climate change effects on future water resources.

\section{Introduction}

Increasing awareness of the secondary effects of climate change brings the groundwater situation of the North Sea coastal region into the focus of research, especially the aspect of ensuring the water supply in the future. The rising interest in the impacts of climate change on groundwater demands a better understanding of groundwater systems (Green et al., 2011; Holman et al., 2012). Especially saltwater intrusion into groundwater systems is considered to be a primary climate change impact on water status (European Commission, 2009). On the barrier islands of the German North Sea coast, the groundwater situation is characterized by the saltwater environment.

In preparation for groundwater modelling to assess the effects of climate change, a 3-D geological model is elaborated for the North Frisian Island of Föhr. Unlike the East Frisian Islands (e.g. Sulzbacher et al., 2012), the North Frisian Islands are not typical barrier islands, but include a Geest core (Sect. 2). Additionally, glacial overprinting of 
the sedimentary layers leads to a unique, complex geologi$\mathrm{cal} /$ hydrogeological situation.

The main objective of this paper is the application and interpretation of geophysical methods to coastal aquifer studies and the compilation of geophysical and geological information into a 3-D model, exemplarily shown for the Island of Föhr. To improve the understanding of the geological and hydrogeological situation down to $300 \mathrm{~m}$ depth and to identify important hydraulical structures potentially affecting the groundwater flow system, an intensive geophysical investigation plan was carried out. The methods used were chosen according to their convenience for structural and parametrical information for the hydrogeological model. A 3-D overview is supplied by airborne electromagnetic survey, 2-D seismic surveys generate a more detailed structural image of the subsurface, and boreholes, as well as borehole measurements contribute in-situ 1-D information. A combined analysis supports and stabilizes the data interpretation of all the methods and is the basis for a reliable interpretation. Studies with related combinations of methods are shown, e.g. by Jørgensen et al. (2012), Bosch et al. (2009), Rumpel et al. (2009), Sulzbacher et al. (2012) and Gunnink et al. (2012).

The high density of geophysical data (airborne electromagentics SkyTEM, seismic reflection in P- and S-wave configuration, vertical seismic profiles) in connection with the high density of boreholes and logs in the Geest area of Föhr provide a good database for petrophysical considerations that are still a need in hydrogeophysics (e.g. Lesmes and Friedman, 2005; Pride, 2005). These considerations should contribute to improved rock identification based on seismic and resistivity results. The rocks or soils of interest on the Island of Föhr are clay, silt, till (aquicludes), sand and gravel (aquifers). Priority in interpretation in this study is on rock/soil properties and not on the chemical status of the pore fluid.

\section{Geological and hydrogeological background}

For a better understanding of the hydrogeological situation, the sedimentation history is shortly summarized (Gripp, 1964; Gürs, 2005; StUA Schleswig, 2006). Föhr is, with $82 \mathrm{~km}^{2}$, the second largest German island in the North Sea (Fig. 1a), located in the North Frisian part of the Wadden Sea. The landscape of the area was mainly formed during the glacial epoch (Saalian and Weichselian glaciations) and the post-glacial time (Holocene) of the Quaternary age. The genesis of the pre-Quaternary strata was influenced by the sedimentation of the Northern German Basin (e.g., Littke et al., 2008). Föhr, as a part of this area of subsidence, is placed on top of a succession of about $4 \mathrm{~km}$ of heavy layers of sedimentary rocks that have been deposited during the past 280 million years. Since the Cretaceous age there had been constant marine conditions for sedimentation in the area that did not change until the youngest Tertiary. For this reason, marine clay is found as the dominating deposit in the Tertiary up to the Miocene. In the Pliocene a regression of the sea resulted in a change from marine to terrestrial facies. The sedimentation changed from clayey to sandy deposits, caused by increasing transport of coarse grained material into the region by a widely braided river system that had its origin in the Baltic-Scandinavian area (Gürs, 2005). At the end of the Pliocene age, sandy material (Kaolin Sand) covered the whole landscape when a change in the global climate marked the beginning of the Pleistocene in the Quaternary age. During the glacial stages the processes of erosion and sedimentation were caused by the action of glaciers and meltwaters. In Northern Germany especially, the glaciers of different glacial stages deeply eroded the underlying strata and formed an expansive system of tunnel valleys that were refilled with glacial deposits and are buried today. Additionally, the preQuaternary subsurface was tectonically disturbed by glacial pressure and thrust in many areas (Aber and Ber, 2007).

The ice front of the last glaciation, the Weichselian stage, did not reach the region at the North Sea coast, so that in the beginning of the Holocene the landscape was covered by Saalian moraine areas and outwash plains. Weichselian sediments are restricted to only some minor occurrences of meltwater sand. At the end of the Pleistocene, the sea level of the North Sea was about $100 \mathrm{~m}$ below the present-day height. During the marine transgression in Holocene, the coastline was moving eastward while the old landscape became more and more flooded by the sea. The eroded material was transported and deposited by tidal currents. Tidal mud deposits, settled during high tide, were accumulated and formed large marshland areas, which have been protected by dikes since about $1000 \mathrm{yr}$. Several heavy floods in historical times caused the loss of large parts of the former mainland area and the breakup into the tidal flat areas of the North Frisian Wadden Sea with the islands as we can see them today.

The landscape of Föhr can be divided into two parts. The south of the island is mainly built up by sand and till of Saalian age, which are the remains of the ancient Saalian land surface. This area, the Geest, is elevated up to $12 \mathrm{~m}$ above sea level (Fig. 1b), and hosts the main water resources of the island. The northern part consists of flat marshland where Holocene tidal mud deposits cover the Pleistocene sediments (Fig. 1c), and is dominated by saline groundwater.

The Quaternary and the Pliocene and Miocene strata of the younger Tertiary were the object of the current investigation. The geological cross-section (Fig. 2) shows the layer succession of the subsurface of the island down to $-120 \mathrm{~m}$ mean sea level (m.s.l.). Two buried valleys were encountered where the Quaternary deposits cut deeply into the older sediments. Such buried valleys may have a significant effect on groundwater flow (Seifert et al., 2008) and salt water intrusion (Mulligan et al., 2007; Jørgensen et al., 2012). The Pliocene sand and the Miocene clay have been strongly tectonically influenced by glacial thrusting. Tectonical structures have also been found to significantly influence saltwater migration in the subsurface (Nishikawa et al., 2009). Hence, 

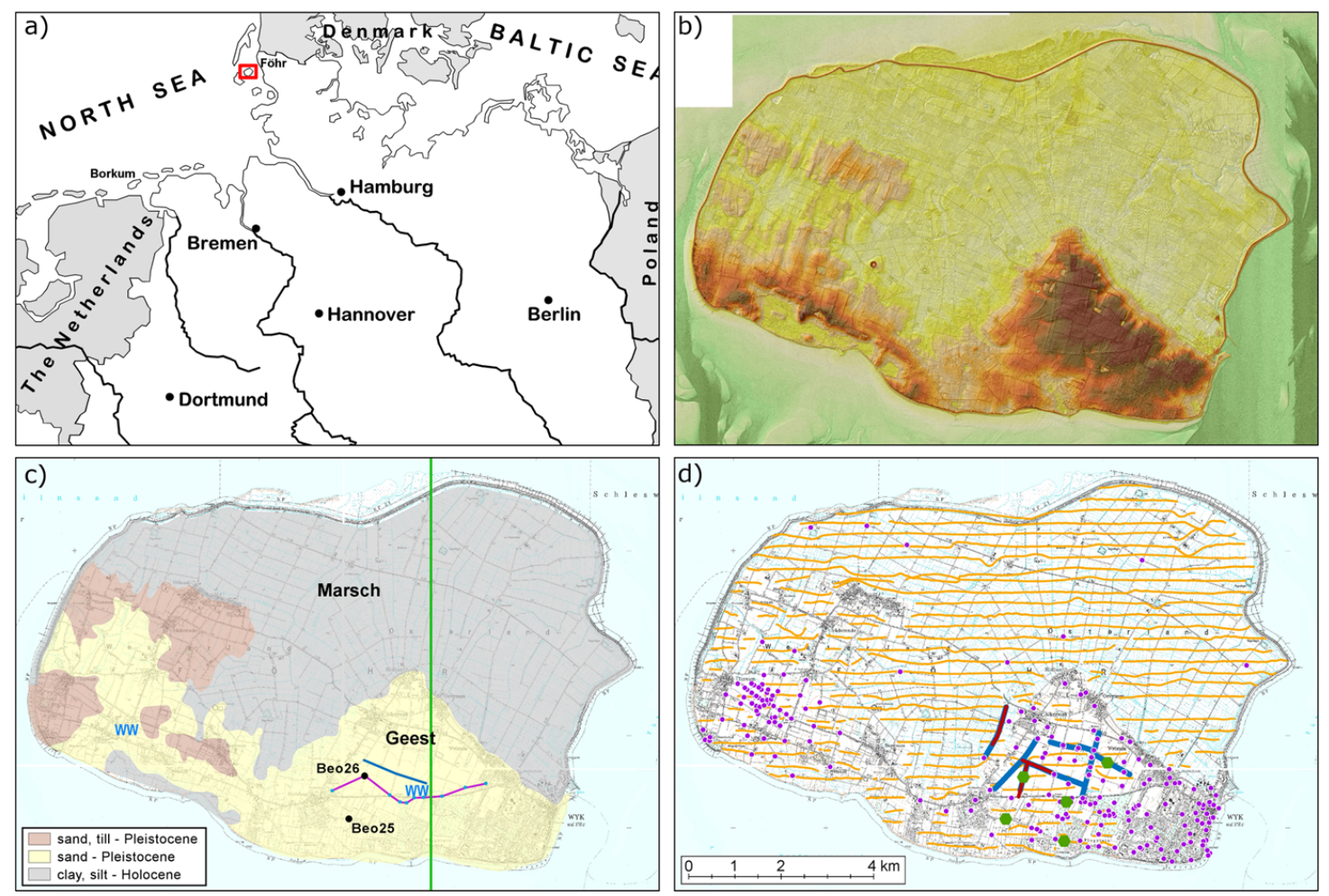

Fig. 1. (a) Overview map of Northern Germany. The red box marks the location of Föhr. (b) Hypsometric map of Föhr (dark greens for lower elevations up through yellows/browns for higher elevations, max. height is $12 \mathrm{~m}$ ). (c) Geological map of the near surface layers (Geest: brown, yellow; marsh: grey), location of the waterworks (blue WWs), analogue geological cross-section (purple line; Fig. 2), boreholes (black dots; Fig. 3), example profile (blue line; Figs. 4, 5, 8), and model cross-section (green line; Fig. 10b). (d) Geophysical surveys (SkyTEM flightlines: yellow; P-wave seismic reflection lines: blue; S-wave seismic reflection lines: red; boreholes with vertical seismic profiles: green) and boreholes (purple).

a sound understanding of the geological features and physical and chemical parameters in the subsurface is imperative for the understanding and modelling of the fresh/saltwater distribution in coastal aquifers.

Due to the high groundwater recharge in the sandy areas of the Geest in the southern part of the island, a large freshwater body was formed. Investigations have shown that freshwater can be found down to more than $-80 \mathrm{~mm}$.s.l. in the central parts of the Geest. There are two waterworks that supply the demand for drinking water on Föhr. The production wells mostly have their screens in the near surface Pleistocene aquifers. In addition, there are two deep wells of the waterworks in the eastern part of the island extracting groundwater from the Pliocene aquifer (Kaolin sand).

In the flat marsh areas in the northern part of the island, only a thin layer of freshwater overlays the saltwater.

\section{Materials and methods}

All geophysical survey and borehole locations are shown in Fig. 1d.

\subsection{Airborne electromagnetic data}

Electromagnetic (EM) induction is the most viable tool for hydrogeological studies because the measurements of electrical conductivity respond to both lithological and waterchemistry variations (Paine and Minty, 2005). Through EM induction eddy currents are created, and therefore no contact with the ground is required. Thus, airborne application is possible. Airborne electromagnetic (AEM) systems allow a fast mapping of the resistivity distribution of the subsurface (Fountain, 1998; Siemon et al., 2009). By the variation of resistivity values, chemical groundwater status and/or geological features and, thus, aquifer structure can be detected and mapped (Burval Working Group, 2009; Jørgensen and Sandersen, 2009; Jørgensen et al., 2012). Especially groundwater salinization and saltwater intrusion into coastal aquifers provoke high conductivity or low resistivity (Siemon et al., 2007) and can be detected very well. However, particular care must be taken to distinguish between fluid resistivity and lithology (Günther and Müller-Petke, 2012). Frequencydomain and time-domain airborne applications are available, and their worth has been proven during the last $10 \mathrm{yr}$ (Siemon et al., 2009; Steuer et al., 2007). 


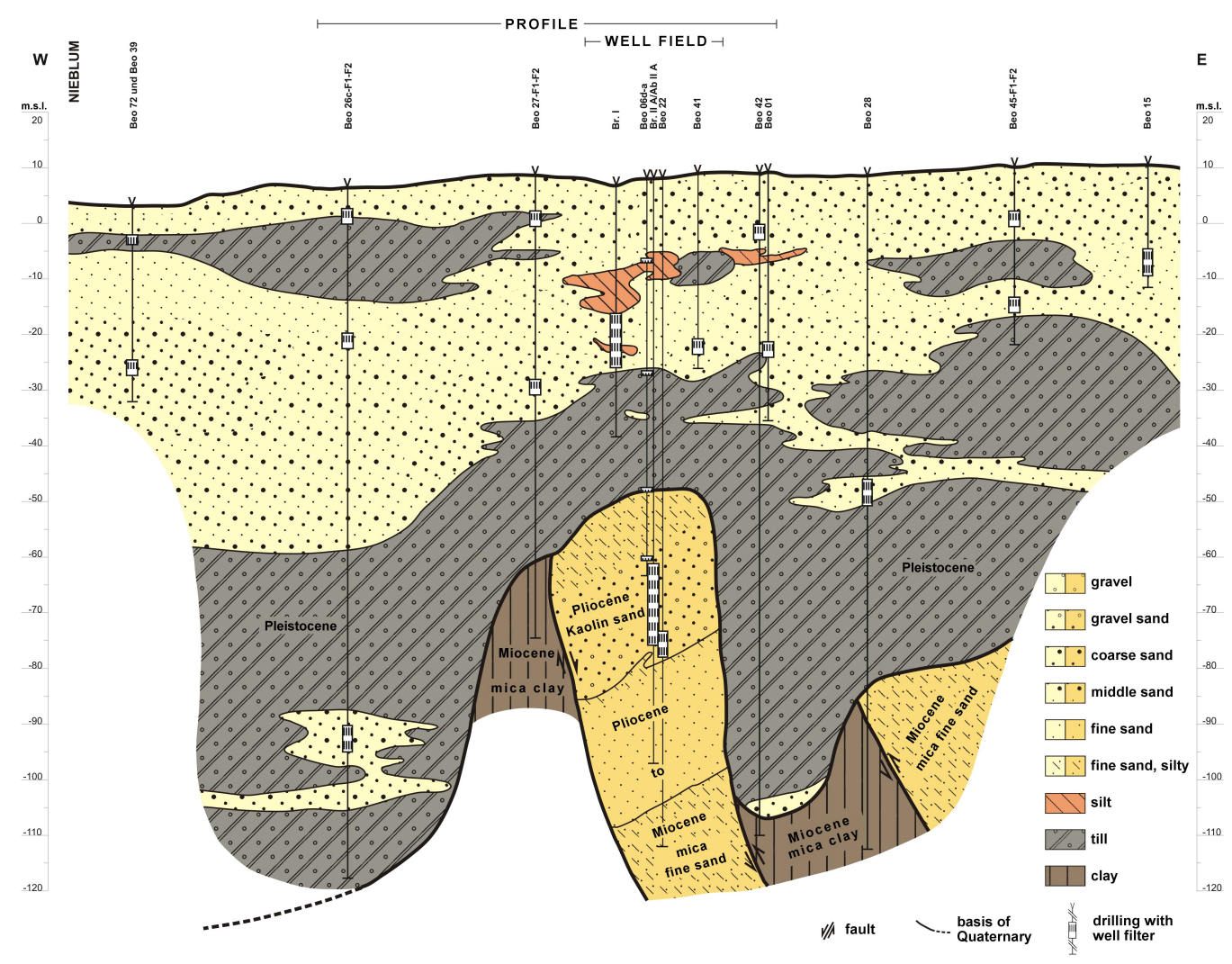

Fig. 2. Analogue geological cross-section (based on boreholes and logs) of the eastern Geest showing two buried valleys and thrust structures in the Pliocene and Miocene strata caused by glaciotectonic processes. The view is 20-times exaggerated. The location of the cross-section is shown in Fig. 1c.

For Föhr a time-domain airborne transient electromagnetic (TEM) survey was commissioned by the Leibniz Institute for Applied Geophysics (LIAG) and carried out with the SkyTEM system (Sørensen and Auken, 2004) by SkyTEM ApS in 2008. The whole island was surveyed in two days with 4 flights and $32 \mathrm{E}-\mathrm{W}$ lines adding up to 306 line $\mathrm{km}$. The nominal flight line spacing of $250 \mathrm{~m}$ and the point spacing of 20-30 $\mathrm{m}$ between single soundings ensure a good coverage of aquifers, aquitards and saltwater intrusions. Low and high transmitter moments (20750 $\mathrm{Am}^{2}$ and $188000 \mathrm{Am}^{2}$, respectively, time gate $10 \mu \mathrm{s}-7 \mathrm{~ms}$ ) enable a good resolution with a maximal penetration depth of about $30-300 \mathrm{~m}$ depending on the local resistivity. The nominal transmitter altitude was about $30 \mathrm{~m}$ above ground level and the flight speed about $70-80 \mathrm{~km} \mathrm{~h}^{-1}$. The collected data generally show a good data quality. The apparent resistivity data points are inverted to a resistivity depth distribution. With the assumption of layered strata, the inversion, using 1-D models and lateral or spatial constraints (LCI and SCI, respectively), generates an appropriate resistivity model of the subsurface (Auken and Christiansen, 2004; Viezzoli et al., 2008; Christensen et al., 2009). The inversion was carried out by Aarhus Geophysics ApS with 5-layer and smoothed 18-layer resistivity models (Auken et al., 2009).

\subsection{Seismic methods}

Seismic methods are a good complement to AEM. They utilize differences in mechanical properties of geologic units. They cannot be used to detect saltwater directly, but they can delineate the boundaries of units which may influence the position and movement of the saltwater interface (Stewart, 1999). With high-resolution seismic surveys using compressional and shear waves (P- and S-waves), detailed structural images of the shallow subsurface down to $500 \mathrm{~m}$ are feasible (Pugin et al., 2009).

For the conversion of seismic time sections into seismic depth sections, realistic seismic velocities are crucial. Accurate velocities can be obtained by vertical seismic profiling (VSP) that can be applied in existing groundwater observation wells.

On Föhr 2-D high-resolution seismic surveys were carried out by LIAG during 2009 and 2011. All in all, 7 profiles with P-waves $(8.0 \mathrm{~km}), 3$ profiles with $\mathrm{S}$-waves $(2.4 \mathrm{~km})$ and VSPs with both P-and S-waves in 5 boreholes (maximal geophone depth 39-102 m) were acquired. LIAG's hydraulically driven vibrator systems MHV2.7 and HVP-30 (Buness and Wiederhold, 1999) were used as seismic sources for Pwave surveys and MHV4S (Polom et al., 2010) for S-wave 
Table 1. Acquisition parameter for seismic surveys.

\begin{tabular}{|c|c|c|c|}
\hline & P-wave & S-wave & VSP \\
\hline Receiver & $\begin{array}{l}\text { planted z-geophones } \\
\text { Sensor SM7 }(20 \mathrm{~Hz})\end{array}$ & $\begin{array}{l}\text { LIAG landstreamer } \\
\text { with SH-geophones } \\
(10 \mathrm{~Hz})\end{array}$ & $\begin{array}{l}\text { borehole geophone } \\
\text { Geostuff (3-components, } \\
14 \mathrm{~Hz})\end{array}$ \\
\hline Receiver spacing & $2 \mathrm{~m}$ & $1 \mathrm{~m}$ & $1 \mathrm{~m}$ \\
\hline Source & MHV2,7/HVP-30 & MHV4S & MHV2,7/ELVIS-6 \\
\hline Source spacing & $4 \mathrm{~m}$ & $4 \mathrm{~m}$ & constant \\
\hline Sweep & $30-240 \mathrm{~Hz}, 10 \mathrm{~s}$ & $30-160 \mathrm{~Hz}, 10 \mathrm{~s}$ & $30-160 \mathrm{~Hz}, 10 \mathrm{~s}^{*}$ \\
\hline $\begin{array}{l}\text { Common-midpoint } \\
\text { spacing }\end{array}$ & $1 \mathrm{~m}$ & $0.5 \mathrm{~m}$ & - \\
\hline
\end{tabular}

* Sweep frequency and length were adjusted during the surveys.

surveys. For VSP measurements the small electro-dynamical vibrator system ELVIS (Polom et al., 2011; Krawczyk et al., 2011) was used as a seismic source. Adequately chosen acquisition parameters (Table 1) as well as thorough processing provide good structural images of the subsurface. Processing steps for seismic reflections were, for example, spectral whitening, dip move-out and normal move-out correction, as well as common midpoint stacking (Yilmaz, 2001). Velocity analysis was done in an iterative way resulting in improved velocity depth sections. Time-to-depth conversion was done by a single interval velocity depth function from VSP (Beo26) above $-100 \mathrm{~m}$ m.s.l. and from stacking velocities below $-100 \mathrm{~m}$ m.s.l.

\subsection{Borehole logs and petrophysical analysis}

To verify seismic and electromagnetic results, a direct link to the subsurface is required. Groundwater observation wells and water supply wells are a good basis for the combined interpretation and geological models. The lithology description combined with borehole logging results is the main source of geological knowledge.

On Föhr a dense borehole coverage exists and provides a good geological background. In 1960 the waterworks started to install pumping and observation well systems via flush drillings. The boreholes reach a maximum depth down to $-120 \mathrm{~m}$ m.s.l. For most of them standard borehole logs are available, e.g. gamma ray (GR) and resistivity logs (short and long-normal 64"), and focussed electrical log (FEL) (Fig. 3). The lithology information is digitized by defining 18 lithological or petrophysical classes from clay to gravel (Table 2).

Borehole logs are also compared with SkyTEM resistivity and seismic velocities from VSP (Fig. 3). This is done for all available data from boreholes with a minimum depth of $75 \mathrm{~m}$, i.e. 18 boreholes located in the eastern Geest area. If a borehole is not in the immediate vicinity of a SkyTEM flightline, the nearest projected SkyTEM sounding was used. For comparison, the borehole logs as well as the SkyTEM resistivity models were resampled in $1 \mathrm{~m}$ intervals, while VSP receiver spacing of $1 \mathrm{~m}$ meets the same sampling interval.

\subsection{Combined analysis}

Combined analysis and interpretation provide more reliability to geophysical and geological data for geological modelling. Mutual information transfer among different geophysical methods or inclusion of geological information leads to matching results for processing (seismic data) and inversions or modelling (SkyTEM data).

Seismic reflection method provides good structural information of the subsurface (Fig. 4a), while resolution of structures from AEM data is poor (Fig. 4b). The resolution can be enhanced by specifying a-priori knowledge to constrain the inversion (Burschil et al., 2012). For the SkyTEM data inversion of Föhr, we included depth information of evident seismic horizons in the inversion process. Also, regarding the geological cross-sections, we recalculate the inversion with a 6-layer resistivity model (Fig. 4c). The improved resistivity distribution was used for parameter correlation (Sect. 4.1) and structural interpretation (Sect. 4.2).

The evaluation of all data is an iterative process. For interpretation all geophysical and geological results have to be taken into account. The data have to be evaluated concerning reliability and consistency among the methods. After several iterations geophysical and borehole data (Fig. 5a) form a geological section (Fig. 5b) and can be implemented into the 3-D model.

\subsection{3-D model}

The 3-D model is built with the GOCAD ${ }^{\circledR}$ software (Paradigm Ltd.) in an iterative way. The original geological model of Föhr is based on the integrated analysis of data from hydrogeological investigations for groundwater exploration and groundwater protection purposes in the past $50 \mathrm{yr}$.

A starting model was built from the analogue model, consisting of geological cross-sections. The information of this model was restricted to the area where borehole and hydrogeological data are present, i.e. the Geest area. To extend the information content spatially, SkyTEM resistivity and 2D seismic depth sections are added to the 3-D model. The 

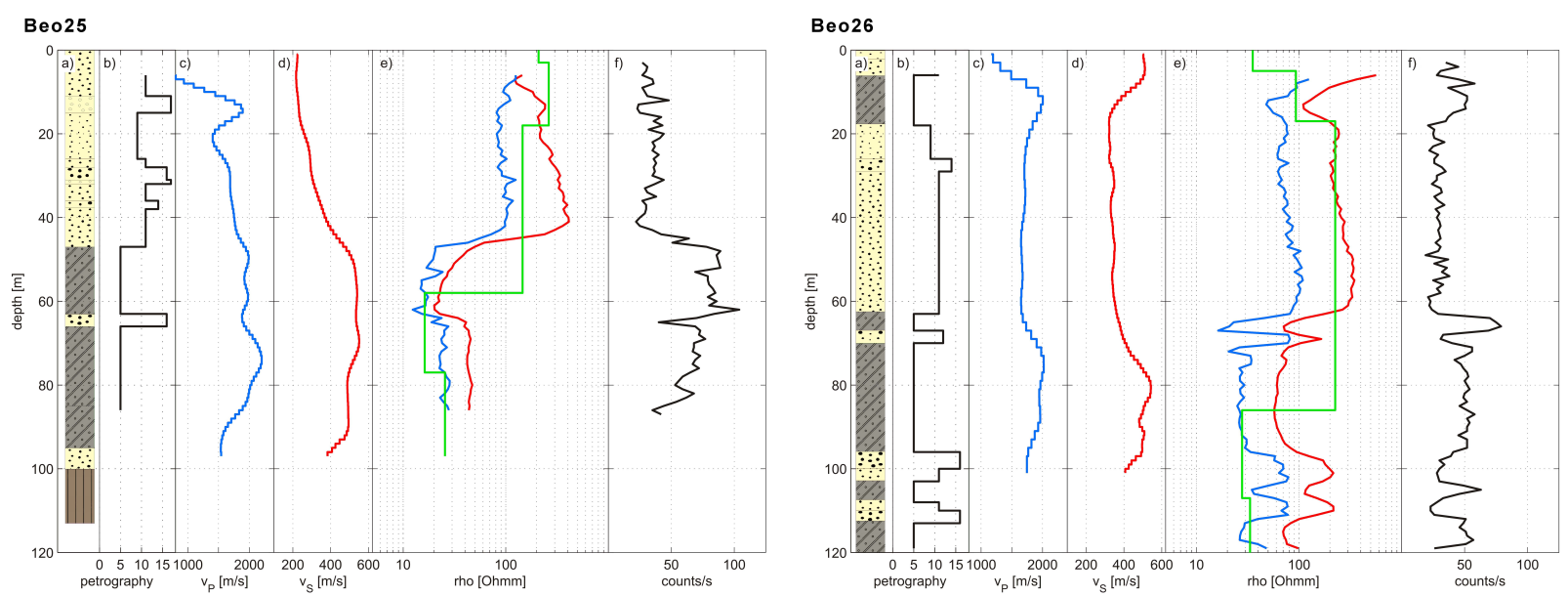

Fig. 3. Example logs for borehole Beo25 (left panel) and Beo26 (right panel) (see Fig. 1c): (a) lithology (see Fig. 2); (b) petrographical classification (see Table 2); (c) P-wave seismic interval velocity from VSP; (d) S-wave seismic interval velocity from VSP; (e) resistivity values for long-normal 64" (red), FEL (blue) and nearby SkyTEM inversion model (green) with offset (Beo25: $177 \mathrm{~m}$; Beo26: $13 \mathrm{~m}$ ); and (f) gamma ray $\log$. Note that the SkyTEM resistivity values do not fit exactly to the resistivity logs due to the horizontal offset of the SkyTEM data points and the large integration volume of this method. For Beo25 the two till layers differ in resistivity as well as gamma log.

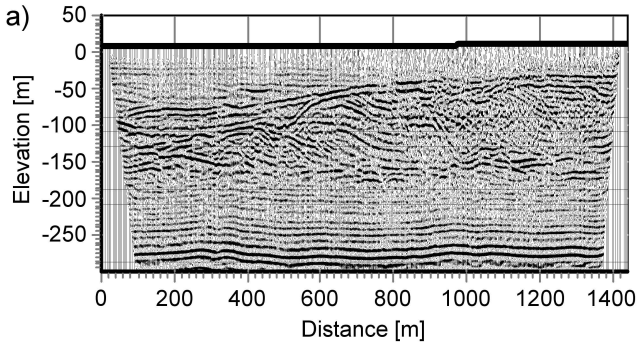

c)

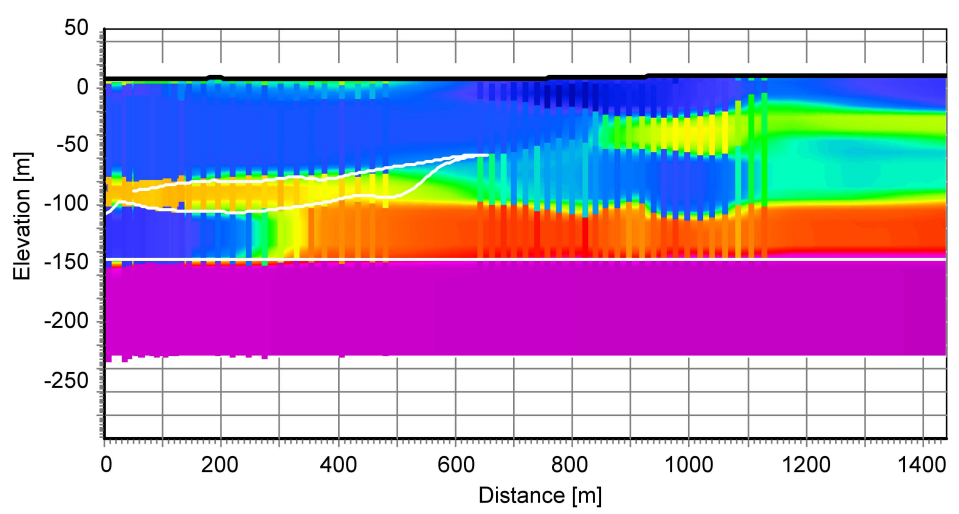

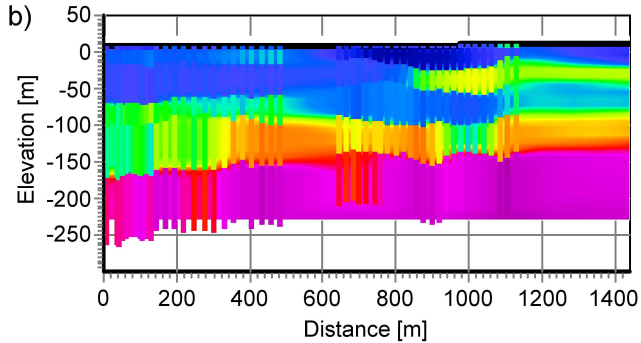

d)

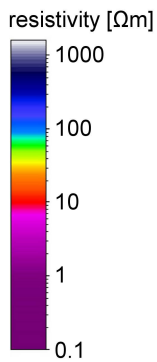

Fig. 4. Improvement of SkyTEM inversion with constraints from seismic reflections: (a) seismic reflection profile (for location see Fig. 1c); (b) resistivity cross-section for 6-layer SCI; (c) resistivity cross-section for 6-layer SCI with additional constraints (white lines) from seismic horizons; and (d) resistivity colorscale.

relevant geological units were elaborated from geophysical and petrophysical information and boreholes, and then $2 \mathrm{~N}-$ $\mathrm{S}$ and $5 \mathrm{E}-\mathrm{W}$ cross-sections were constructed (Fig. $5 \mathrm{c}$ ). Geological surfaces were embedded between these construction cross-sections. The morphology of the geological layers has been adapted according to the geophysical data.
The SkyTEM resistivity data also help to identify the spatial distribution of aquifers filled with freshwater on the one hand, and to outline the areas where clay or/and saltwater is found on the other hand. For this, a threshold value of $50 \Omega \mathrm{m}$ was chosen, according to our evaluated petrophysical results (Sect. 4.1), i.e. sediments with a resistivity above $50 \Omega \mathrm{m}$ is considered to have fresh porewater. 

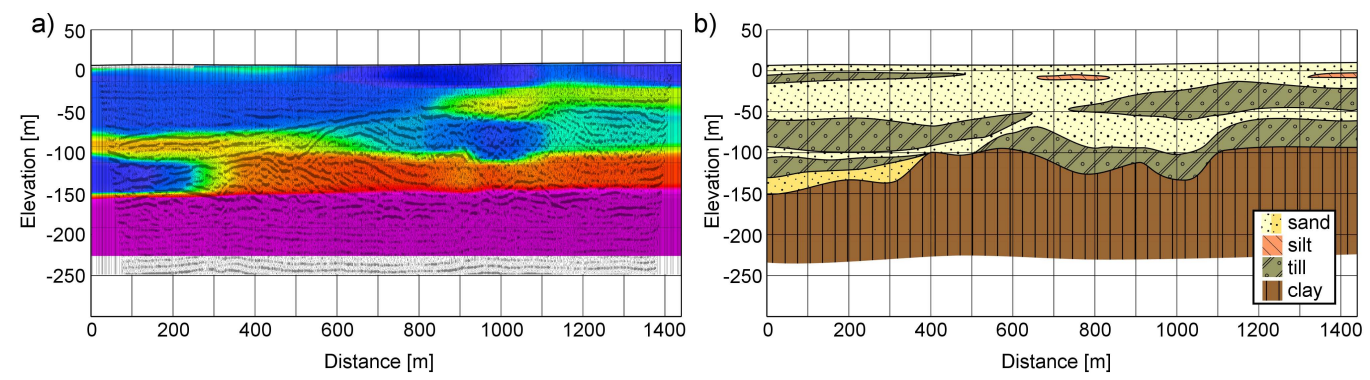

c)
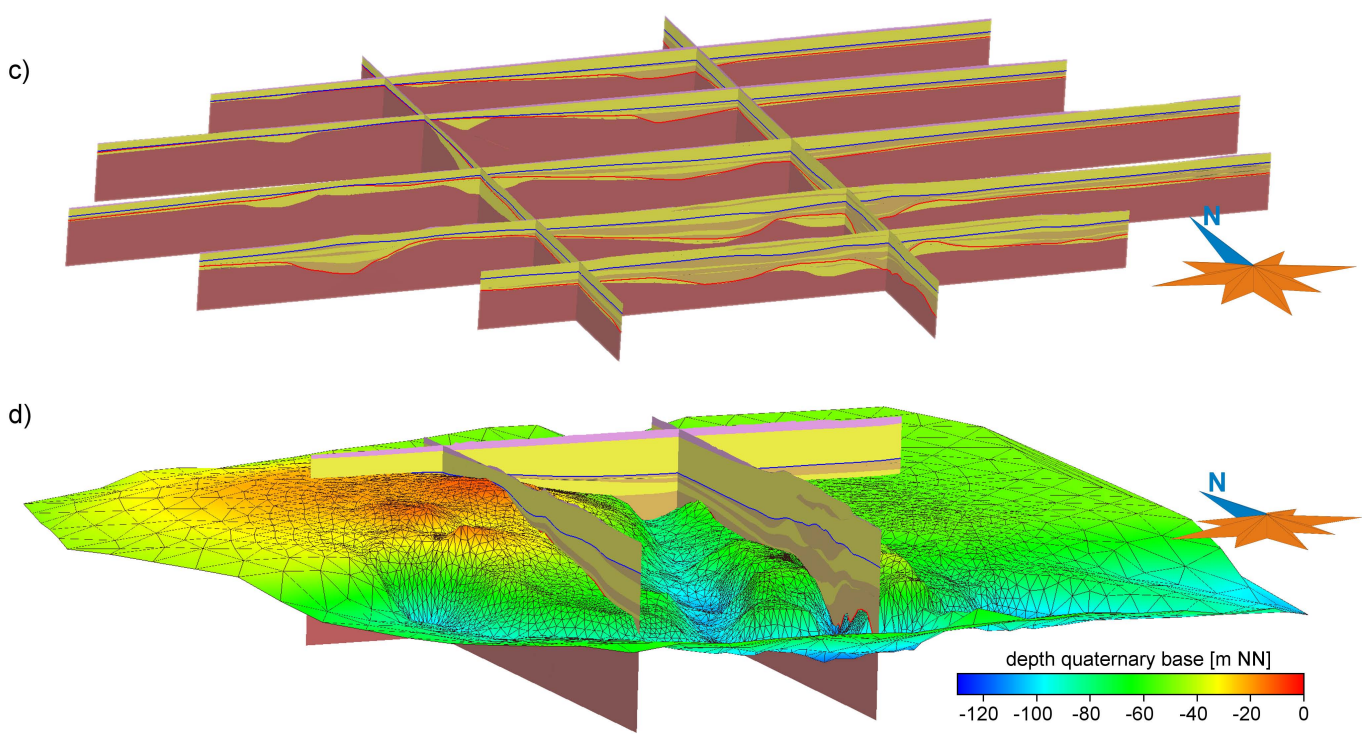

Fig. 5. Development of 3-D model: (a) seismic reflection profile with overlying SkyTEM resistivity values (for colorscale see Fig. 4d); (b) geological cross-section from boreholes, seismic reflections, and SkyTEM resistivity values; (c) fence diagram of construction crosssections used to generate the 3-D model (yellow: aquifers; brown/red: aquitards; blue line: base of 2nd aquifer; red line: base of Quaternary strata)(the view is 5-times exaggerated); and (d) 3-D view into the 3-D model showing one layer (Quaternary base) and three construction cross-sections (the view is 20 -times exaggerated).

In total 12 surfaces are constructed displaying four Pleistocene and two Tertiary aquifers which are covered by five Quaternary and one Tertiary aquitards (example of one layer is shown in Fig. 5d). All layers are globally present and continuous throughout the area. In parts where a geological unit is not present, the thickness of this layer was reduced to zero.

\section{Results and discussion}

The results concern on the one hand petrophysical properties that are needed for the interpretation as well as discrimination of sand, till and clay, and on the other hand the structural architecture of the subsurface described by the 3-D model. All these data are imperative for the development of a groundwater model with a sound description of the subsurface and useable for climate change impact modelling (LLUR, 2012).

\subsection{Petrophysical properties and rock identification}

The following considerations are valid for the Geest area where the main freshwater body is present. Sediments in the Geest are freshwater saturated down to at least $-150 \mathrm{~m}$ m.s.l., and in the interpretation no collision with saline pore water occurs. Near surface effects from dry material were considered, but can be neglected.

\subsubsection{Resistivity}

Using electrical resistivity for the discrimination of clayey and clay-free sediments seems to be easy, since resistivity of clay-free sediments follows Archie's law that electrical current flow is predominantly through the pore water (Archie, 1942), while for clayey sediments the surface conductivity of clay minerals plays an important role in the current flow. So formula to calculate resistivity of clayey sediments have to account for surface conductivity (e.g. Frohlich and Parke, 1989) or cation exchange capacity (e.g. Sen et al., 1988). For 
Table 2. Petrographical classification and petrophysical parameters: mean values, standard deviation and number of counts for common logarithm of resistivity and seismic velocities.

\begin{tabular}{|c|c|c|c|c|c|c|}
\hline Lithology & $\begin{array}{l}\text { Petrographical } \\
\text { classification }\end{array}$ & $\log _{10} \rho_{\text {long-normal }}$ & $\log _{10} \rho_{\mathrm{FEL}}$ & $\log _{10} \rho_{\text {SkyTEM }}$ & $v_{\mathrm{P}}\left[\mathrm{ms}^{-1}\right]$ & $v_{\mathrm{S}}\left[\mathrm{ms}^{-1}\right]$ \\
\hline clay & 1 & $1.63(42.5 \Omega \mathrm{m}) \pm 0.05(14)$ & $1.34(21.7 \Omega \mathrm{m}) \pm 0.09(12)$ & $1.48(30.1 \Omega \mathrm{m}) \pm 0.39(37)$ & - & - \\
\hline clay, silt/silt, clay & 2 & $1.53(34.2 \Omega \mathrm{m}) \pm 0.32(86)$ & $1.32(21.0 \Omega \mathrm{m}) \pm 0.24(84)$ & $1.18(15.0 \Omega \mathrm{m}) \pm 0.41(169)$ & $1830.4 \pm 318.9(52)$ & $436.5 \pm 82.9(52)$ \\
\hline silt & 3 & $2.20(158.5 \Omega \mathrm{m}) \pm 0.17(33)$ & $1.81(64.8 \Omega \mathrm{m}) \pm 0.22(15)$ & $1.98(95.8 \Omega \mathrm{m}) \pm 0.33(37)$ & $2125.2 \pm 63.6(3)$ & $282.9 \pm 1.8$ \\
\hline clay/silt, fine sand & 4 & $1.63(42.4 \Omega \mathrm{m}) \pm 0.09(7)$ & - & $1.32(21.1 \Omega \mathrm{m}) \pm 0.39(45)$ & $1777.7 \pm 206.4(18)$ & $523.6 \pm 37.5(18)$ \\
\hline silt, clay, sand, gravel (till) & 5 & $1.68(47.7 \Omega \mathrm{m}) \pm 0.23(409)$ & $1.42(26.6 \Omega \mathrm{m}) \pm 0.19(289)$ & $1.65(44.4 \Omega \mathrm{m}) \pm 0.39(454)$ & $1934.2 \pm 165.8(80)$ & $480.0 \pm 68.4(80)$ \\
\hline silt, sand, gravel (till) & 6 & $2.08(120.6 \Omega \mathrm{m}) \pm 0.08(2)$ & $1.75(56.9 \Omega \mathrm{m}) \pm 0.10(2)$ & $1.48(30.5 \Omega \mathrm{m}) \pm 0.27(12)$ & - & - \\
\hline fine sand, silt & 7 & $1.97(92.3 \Omega \mathrm{m}) \pm 0.11(52)$ & $1.62(41.4 \Omega \mathrm{m}) \pm 0.09(37)$ & $1.63(42.3 \Omega \mathrm{m}) \pm 0.43(62)$ & - & - \\
\hline fine to coarse sand, silt & 8 & - $\quad$ n n & - & 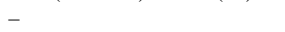 & - & - \\
\hline fine sand & 9 & $2.26(181.1 \Omega \mathrm{m}) \pm 0.20(123)$ & $1.93(85.2 \Omega \mathrm{m}) \pm 0.11(75)$ & $1.87(74.2 \Omega \mathrm{m}) \pm 0.42(273)$ & $1720.4 \pm 202.5$ & $334.6 \pm 84.5(38)$ \\
\hline fine to middle sand & 10 & $2.24(174.1 \Omega \mathrm{m}) \pm 0.24(42)$ & $2.05(111.6 \Omega \mathrm{m}) \pm 0.05(19)$ & $2.07(117.8 \Omega \mathrm{m}) \pm 0.24(128)$ & - & - \\
\hline middle sand & 11 & $2.32(209.8 \Omega \mathrm{m}) \pm 0.25(175)$ & $1.95(89.1 \Omega \mathrm{m}) \pm 0.14(129)$ & $2.03(107.1 \Omega \mathrm{m}) \pm 0.38(275)$ & $1425.8 \pm 464.9(100)$ & $318.6 \pm 71.9(100)$ \\
\hline fine to coarse sand & 12 & $2.09(122.4 \Omega \mathrm{m}) \pm 0.38(114)$ & $1.72(52.2 \Omega \mathrm{m}) \pm 0.31(78)$ & $1.64(44.1 \Omega \mathrm{m}) \pm 0.46(157)$ & $1477.6 \pm 409.8(65)$ & $328.2 \pm 71.1(65)$ \\
\hline fine to coarse sand, gravel & 13 & - & - & - & - & - \\
\hline middle to coarse sand & 14 & $2.41(255.9 \Omega \mathrm{m}) \pm 0.22(45)$ & $2.04(110.8 \Omega \mathrm{m}) \pm 0.14(23)$ & $2.04(110.4 \Omega \mathrm{m}) \pm 0.37(74)$ & $1611.8 \pm 121.6(19)$ & $413.3 \pm 73.2(19)$ \\
\hline middle to coarse sand, gravel & 15 & - & - & - & - & - \\
\hline coarse sand & 16 & $2.21(160.5 \Omega \mathrm{m}) \pm 0.33(63)$ & $1.75(56.7 \Omega \mathrm{m}) \pm 0.22(42)$ & $1.86(72.2 \Omega \mathrm{m}) \pm 0.41(70)$ & $1772.1 \pm 88.7(10)$ & $432.0 \pm 99.9(10)$ \\
\hline gravel, sand & 17 & $2.41(255.6 \Omega \mathrm{m}) \pm 0.08(22)$ & $1.93(85.8 \Omega \mathrm{m}) \pm 0.08(22)$ & $1.84(69.7 \Omega \mathrm{m}) \pm 0.53(22)$ & $1763.7 \pm 118.1(5)$ & $245.3 \pm 35.0(5)$ \\
\hline gravel & 18 & - & - & - & - & - \\
\hline
\end{tabular}

a)

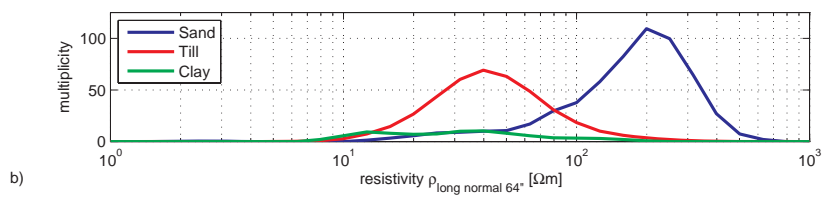

b)

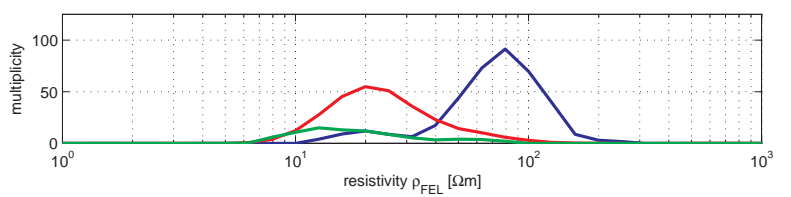

c)

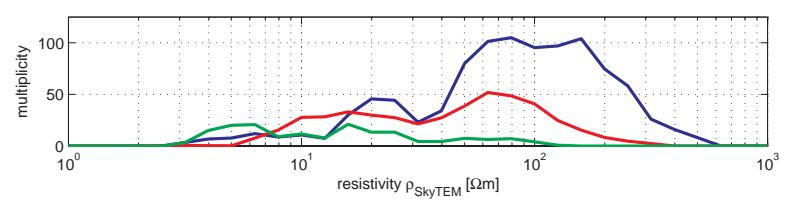

Fig. 6. Histogram of resistivity values from borehole logs and projected SkyTEM resistivity values for petrographical classification of sand, till and clay: (a) long-normal 64"; (b) FEL; and (c) 6layer model of constrained SkyTEM data. Bins are logarithmically equidistant.

freshwater saturated sediments, it can be expected that resistivity of clay-free sands is higher than resistivity of clayey sediments.

To use resistivity as a proxy for lithology, we establish a relationship for this special region. Bosch et al. (2009) did this for a site in the Netherlands by linking borehole lithology to AEM resistivity and deduced a relationship between resistivity and probability of occurrence of clay, fine sand and coarse sand. We use resistivity logs for comparison. All histograms for different resistivity methods (see Fig. 6) demonstrate that the measured values for sand are higher than for clayey material. The resistivity for clay and till is similar. However, overlapping resistivity values for sandy and clayey a)

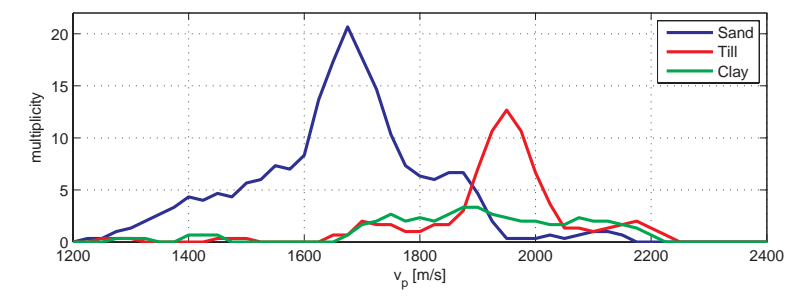

b)

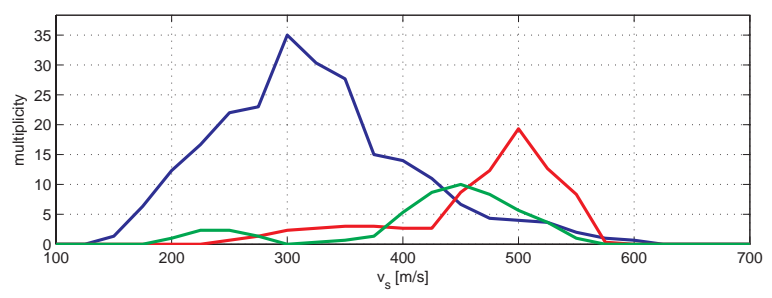

Fig. 7. Histogram of seismic velocities from VSP data for petrographical classification of sand, till and clay: (a) P-wave velocities; and (b) S-wave velocities.

material are found in the range of 50-100 $\Omega \mathrm{m}$. Interpretation problems in this range can be reduced to a minimum by comparing with other methods, i.e. borehole logging or seismic reflection. Nonetheless, discrimination of different lithologies with a wide range of resistivity values is possible. For further lithological characterization of the resistivity volume, we chose $20 \Omega \mathrm{m}$ as the lower till boundary to avoid any saltwater influences and $50 \Omega \mathrm{m}$ for the till/sand boundary. The larger overlapping for SkyTEM resistivity values can be explained by the projection to the borehole locations, resulting in reduced resistivity resolution.

Similar results for Föhr were found by Grabowski (2012) and for the region of Quakenbrück (Niedersachsen) by Klimke (2012). 

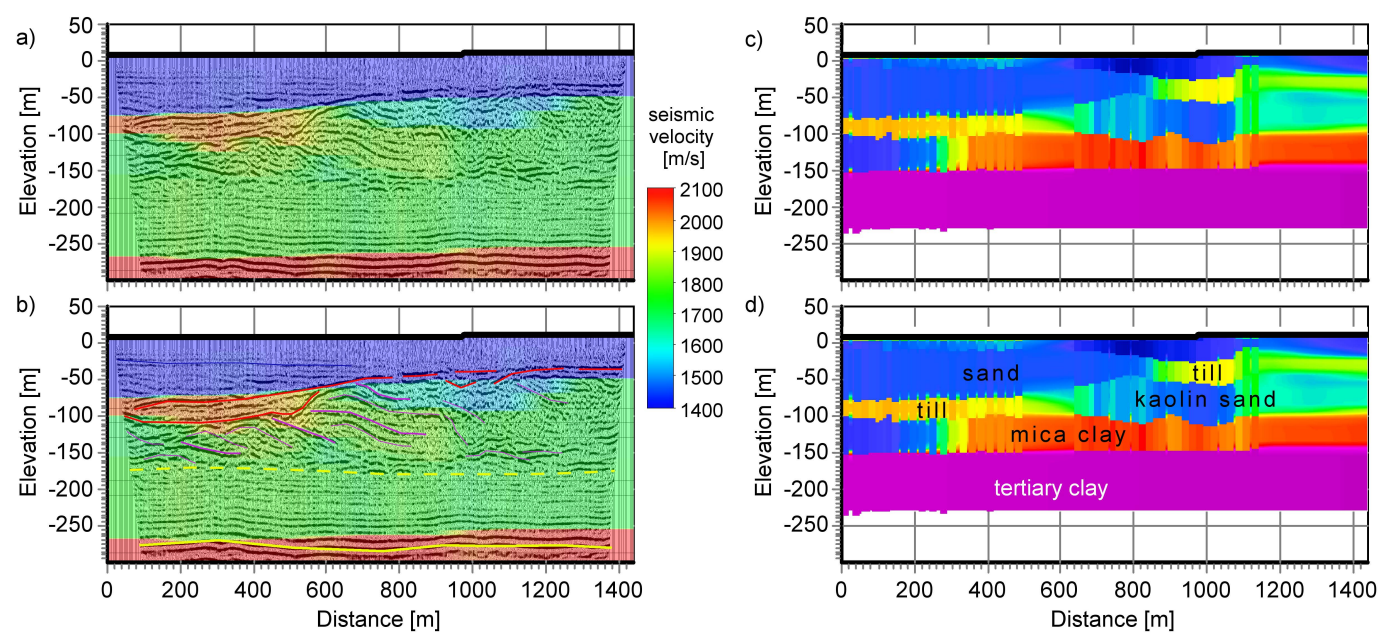

e)

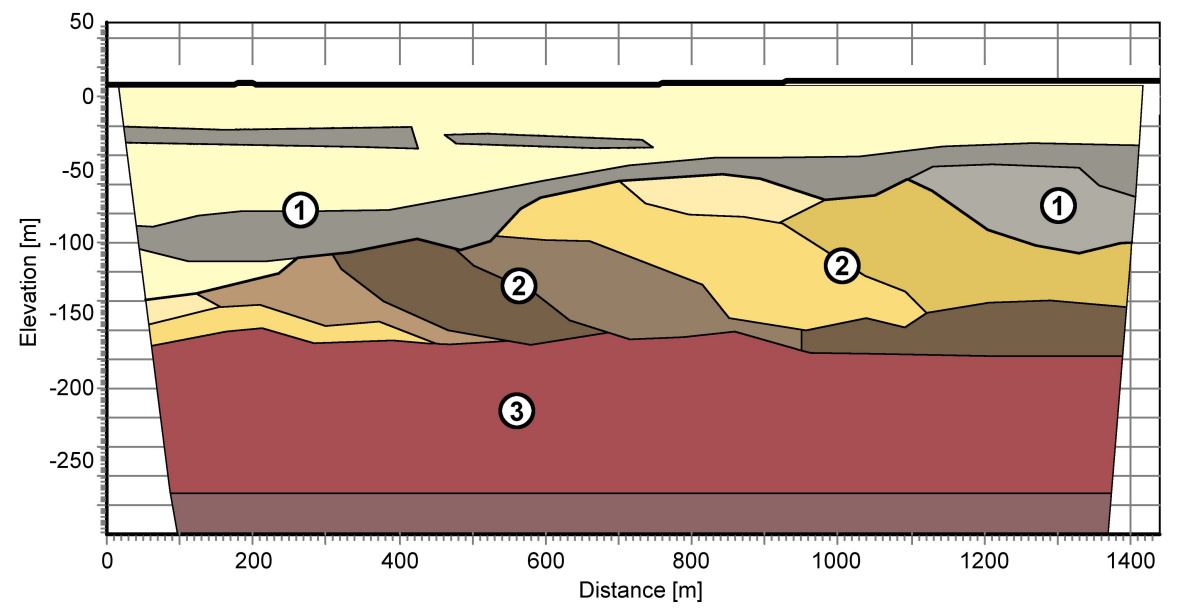

Fig. 8. Structural interpretation of geophysical data: (a) seismic reflection depth section with interval velocities; (b) and marked horizons; (c) SkyTEM resistivity cross-section (for colorscale see Fig. 4d); (d) with interpretation; and (e) interpretated block cross-section with (1) buried valleys (grey: till; bright yellow: sand), (2) glaciotectonic structures below, and (3) undisturbed Tertiary layers.

In general, the resistivity measured with the long-normal borehole equipment is higher than the corresponding resistivity from the SkyTEM survey and the FEL logging (Fig. 6). Anisotropy due to fine layering of the subsurface can be a possible explanation. If low resistivity layers are embedded in the fine-layered sediments, electrical anisotropy leads to reduced resistivity values for current flow parallel to the layering, while for current flow perpendicular to the layering an increased resistivity is measured. Time domain electromagnetic methods with horizontal coils, like with the SkyTEMsystem, create a field of eddy currents for which the predominant flow direction is horizontal, a more or less horizontal current flow is also generated by the FEL logging. This would lead to lower measured resistivity values, while measurements using long-normal resistivity borehole equipment with vertical current flow direction would lead to higher resistivity values.

\subsubsection{Seismic velocity}

Direct access to seismic velocities in relation to lithology is given by vertical seismic profiles at five observation wells. In Fig. 7 in-situ measured seismic velocities for P- and Swaves are shown for sand and till. The velocities of till (about $1950 \mathrm{~m} \mathrm{~s}^{-1}$ ) are in general higher than the velocities of sand (about $1675 \mathrm{~m} \mathrm{~s}^{-1}$ ), even if an overlapping velocity range exists. P-wave velocities below $1500 \mathrm{~m} \mathrm{~s}^{-1}$ (= P-wave velocity of water) are explained by the influence of the uppermost dry layers with very low velocities. It is possible to discriminate between sand and till. Sparse data on clayey material make a discrimination of clay impossible. Even other parameters derived from seismic velocities, i.e. $V_{\mathrm{p}} / V_{\mathrm{s}}$ and Poisson's ratio, allow discrimination of sand, till and clay. A spatial extent to 2-D seismic reflection profiles is difficult for this parameter because less $\mathrm{S}$-wave data was available. 
a)

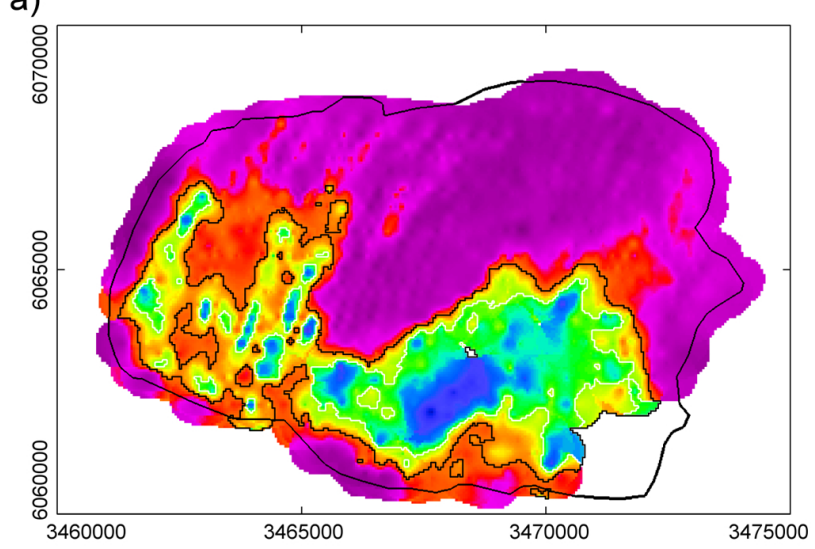

b)

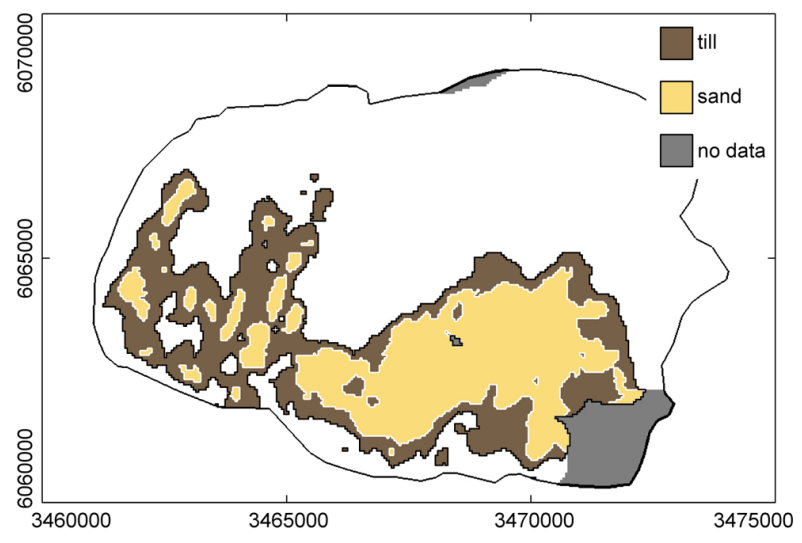

Fig. 9. Depth slice of (a) SkyTEM mean resistivity between -40 to $-50 \mathrm{~m}$ m.s.l. (for colorscale, see Fig. 4d); and (b) lithological interpretation from petrophysical characterization (boundary of till to saline water saturated area is defined by $20 \Omega \mathrm{m}$, boundary of till/sand is set to $50 \Omega \mathrm{m}$ ). Hence, blue-green colours indicate fresh groundwater, and purple-red colours indicate salt water.

A possible explanation for the increased seismic velocity is the reduced porosity of till. If sand and clay are mixed to form till, the tiny clay particles concentrate in the pore space of the sand, reduce the porosity and, by blocking the pore channels, reduce the permeability. This porosity reduction effect was shown by Marion et al. (1992) in laboratory experiments with artificial sand-clay mixtures. The highest seismic velocity was found at about $25 \%$ clay content, depending on the confining pressure.

Mean distribution values for the shown histograms of different resistivity methods and seismic velocities are listed in Table 2.

\subsection{Structural interpretation and 3-D model}

The seismic depth sections allow insight into the geological structures down to a depth of at least $400 \mathrm{~m}$ (Fig. 8a). We recognize three different geological units: The more or less horizontal and undisturbed reflections below $150 \mathrm{~m}$ represent Tertiary layers. Above $150 \mathrm{~m}$ the picture totally changes and the reflection pattern is very complex. Dipping reflections predominate indicating glacial thrust faulting. This glaciotectonic complex is separated from the undisturbed section by a detachment or decollement horizon. Further upwards, this glaciotectonic complex is partly eroded by glacial incision. This valley is filled with glacial deposits. The seismic velocities allow the delineation of sand and till (Sect. 4.1). By its higher velocity, a till layer at the bottom of the valley is detected (Fig. 8b). The resistivity (Fig. 8c, d) emphasises this tripartition (buried valley, glaciotectonic complex and undisturbed Tertiary). The block cross-section with different pushed units of clay and sand and Tertiary layers (Fig. 8e) demonstrates this interpretation more clearly. Varying resistivity in the thrust-fault complex may indicate thrust sand (Pliocene) and clay (Miocene). The parallel occurrence of sand and clay can also be traced in the resistivity depth slices (Fig. 9) via rock identification (Sect. 4.1). As a result of the ice pressure, a pattern of south-north elongated sand bodies of Pliocene kaolin sand alternating with Miocene clay exists, which can be seen in the east to west direction. In the northern part of the slices and below the detachment (about $-150 \mathrm{~m}$ m.s.l.), the very low resistivity points to saltwater occurrence. Thrust faulting is known for Northern Germany and imaged quite well in marine seismic sections offshore the North Frisian Islands (e.g. Koopmann et al., 2010; Andersen, 2004), but onshore imaging in seismic and AEM is scarce. Indications of glaciotectonic complexes are presented by Jørgensen et al. (2012), and further east, in Poland, by Morawski (2004).

The base of the 3-D model (Fig. 10) consists of Miocene clay that is covered by the two Tertiary aquifers, which in some areas are separated by a clayey aquitard. The interpretation of the seismic sections has shown that the bedding of the Tertiary strata is strongly affected by glacial tectonics down to a depth of about $-150 \mathrm{~m}$ m.s.l. The thrust-folded sand bodies were integrated as aquifers in the model; their spatial extension was derived from the resistivity data in combination with rock identification.

The depth of the Quaternary strata varies strongly. In some areas of the western Geest, only Pleistocene cover of 10 to $20 \mathrm{~m}$ thickness exists. Quaternary sediments in buried valleys reach depths of more than $-130 \mathrm{~m}$ m.s.l. The course of the two buried valleys in the eastern part of the island corresponds with the south-north strike of the glacial thrust structures in the Tertiary strata. The fill of the valleys and the deeper part of the Quaternary sediments outside of the valleys mainly consist of fine grained material like clay, silt and till, as known from boreholes.

The near surface Quaternary strata is built up by Saalian meltwater sands, which in wide areas form a non-covered aquifer in the Geest of the island that is hydraulically connected to the 2nd Quaternary aquifer. The 1st and the 2nd aquifer are the production horizon of nearly all wells of the 


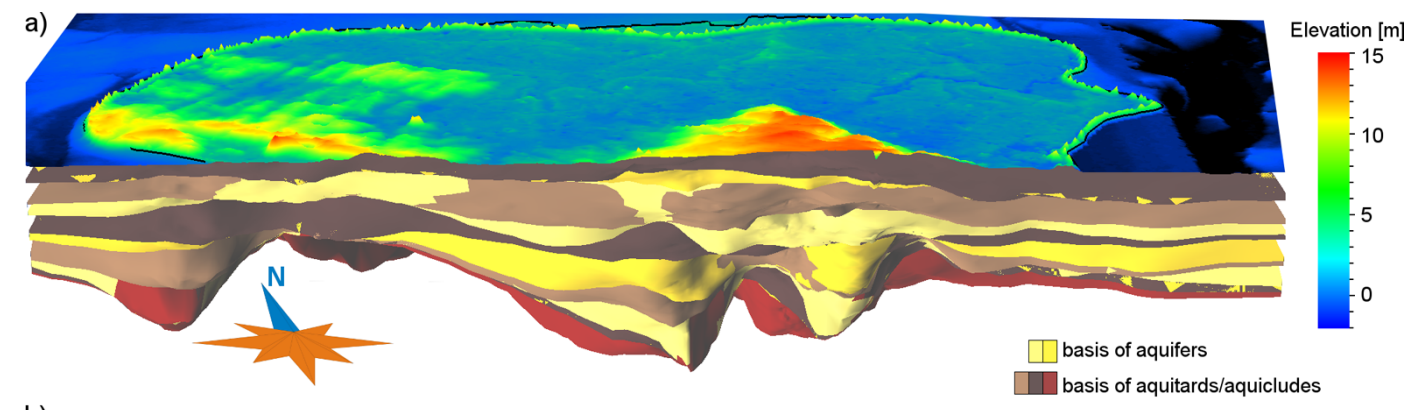

b)

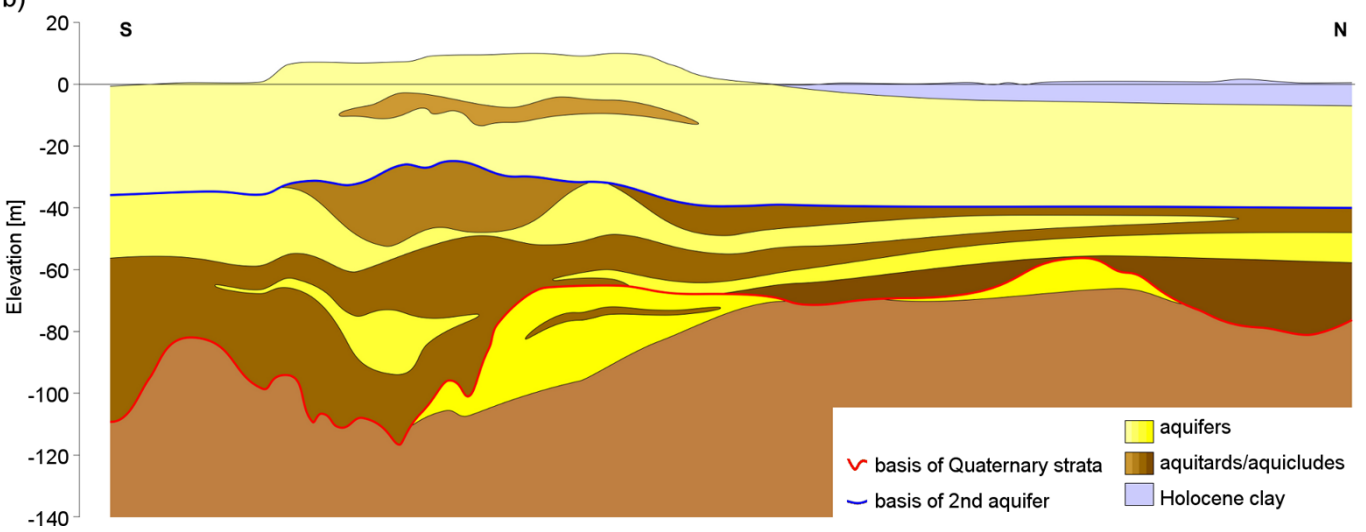

Fig. 10. Final 3-D model: (a) 3-D view into the model; and (b) $10 \mathrm{~km}$-long cross-section through the 3-D model. The location of the section is shown in Fig. 1c.

waterworks. In the marsh the 1 st aquifer is covered by some meters of Holocene clay.

The aim of the digital geological 3-D model was to reproduce the hydrogeological structure of the modelled area as the base for the groundwater model. The groundwater model was built up to show how the hydrogeological system of the island will react to the impacts of the predicted climate changes (LLUR, 2012). The model should be regarded as a simplified model and, due to the lack of detailed data in many parts of the island, not as a model including every complex local detail. In this we are in good agreement with Voss (2011a, b).

Due to the very heterogeneous database with a lot of information in the southern areas around the waterworks and very sparse data in the northern marshland, it was not considered as meaningful to build a geological model representing all complex details only found in some parts of the modelled area. Nevertheless, the complex structures of the aquifers in the deeper parts of the island have been mapped using the SkyTEM resistivity and seismic data in combination with borehole data. The results of this mapping show a significant pattern of glacial thrust structures, which give indications for the construction of the geological model in the northern part of the island where these data do not exist (due to saltwatersaturated sediments).

\section{Limitations}

Borehole information and results from geophysical measurements enable the compilation of the geological/hydrogeological 3-D model. The quality of the assembled data and the experience of the modelling geologist are the major aspects that justify the reliability of the generated model. In the following the data quality is discussed.

Our geophysical data bear a generally good data quality. The SkyTEM data show a low noise level. During processing of SkyTEM data, couplings caused by man-made structures and soundings with poor quality were eliminated, leading to a proper resistivity model. This is the reason for less resistivity data density in the urban area of the eastern Geest. Electromagnetic methods like AEM are dispersive methods with limitations in resolving small-scale structures. The resulting resistivity distribution reflects an integrated volume in the subsurface with decreasing resolution in depth (Høyer et al., 2011). The inversion algorithm claims more or less horizontal-layered environments when using spatial constraints (Auken and Christiansen, 2004). Steeply dipping or major horizontal resistivity contrasts as well as small-scale bodies will not be resolved and are shown as smooth transitions. Depending on this limitation and the width of the footprint, horizontal resolution is limited. The quality of our data inversion is evaluated further by Burschil et al. (2012). 
Our results from seismic reflections have a good signal/noise ratio and show $\mathrm{P}$-wave reflections down to $-700 \mathrm{~m}$ m.s.l. The applied processing scheme was relatively robust, while small changes have no large effects to the seismic section. There is a good correlation of reflections and lithological changes in adjacent boreholes thanks to the proper VSP interval velocities for time-to-depth conversion of the seismic sections. Inaccurate velocities for time-todepth conversion would have affected the observed depth of seismic reflectors and misled the interpretation.

The 3-D model constructor has to consider the reliability of the data. Usually all data from boreholes, seismic crosssections and boundaries in the resistivity models does not fit exactly together. The task is to produce a 3-D model from 1-D borehole data, 2-D seismic cross-sections and 3-D resistivity models consisting of a bundle of 1-D resistivity models. At the end, the model should fit all data and even agree with a plausible geological genesis.

\section{Conclusions}

We have demonstrated that geophysical investigations can provide petrophysical parameters and can improve the geological/hydrogeological model and thus the understanding of the subsurface and the groundwater system. Especially, seismic reflection data in combination with airborne EM (SkyTEM) and borehole information enhance the hydrogeological characterization regarding rock identification and structure, and thus the 3-D model of the subsurface of the Island of Föhr. The SkyTEM resistivity distribution improves the knowledge concerning spatial geological information as well as data on the freshwater interface for areas outside and in between the eastern and western parts of the Geest, where previous work was restricted. The extent of the freshwater occurrence is determined, as well as the extent of glaciotectonic structures. The thrust faulting structures, which presumably affect the groundwater flow system, are clearly defined by the combined interpretation of seismic and resistivity data. The structural interpretation is improved by rock identification.

The main benefit of our work is that the fruitful combination of EM, seismic and borehole data reveals the complex geology of a glacially-affected island. Our understanding of the subsurface structure and the compilation of a 3-D model is the basis for a groundwater flow model to predict climate change effects.

Acknowledgements. We thank Flemming Jørgensen for fruitful discussion and the initial idea of glacial overprinting. Further, we thank Hark Ketelsen and the "Wasserbeschaffungsverband Föhr" for support during our geophysical surveys, as well as Bernd König and Anja Wolf from LLUR. We also acknowledge LIAG's seismic field crew for their excellent work during the surveys.
This article is an outcome of the EU Interreg IVB project CLIWAT (ID 35-2-1-08). It has been co-funded by the North Sea Region Programme 2007-2013 under the ERDF of the European Union.

Edited by: K. Hinsby

\section{References}

Aber, J. S. and Ber, A.: Glaciotectonism, Developments in Quaternary Sciences, 6, Elsevier, Amsterdam, 2007.

Andersen, L. T.: The Fanø Bugt Glaciotectonic Thrust Fault Complex, Southeastern Danish North Sea - A study of large-scale glaciotectonics using high-resolution seismic data and numerical modeling, Ph.D. thesis, Danmarks og Grønlands Geologiske Undersøgeles Rapport 2004/30, 2004.

Archie, G. E.: The electrical resistivity log as an aid in determining some reservoir characteristics, T. Am. I. Min. Met. Pet. Eng., 146, 54-62, 1942.

Auken, E. and Christiansen, A. V.: Layered and laterally constrained 2D inversion of resistivity data, Geophysics, 69, 752761, doi:10.1190/1.1759461, 2004.

Auken, E., Christiansen, A. V., Westergaard, J. H., Kirkegaard, C., Foged, N., and Viezzoli, A.: An integrated processing scheme for high-resolution airborne electromagnetic surveys, the SkyTEM system, Explor. Geophys., 40, 184-192, 2009.

Buness, H. and Wiederhold, H.: Experiences with a vibrator system for shallow high-resolution seismic, Ext. Abst., EAGE 61st Conference and Technical Exhibition, Helsinki, 1999.

Bosch, J. H. A., Bakker, M. A. J., Gunnink, J. L., and Paap, B. F.: Airborne electromagnetic measurements as basis for a 3-D geological model of an Elsterian incision, Z. Dtsch. Ges. Geowiss., 160, 249-258, 2009.

Burschil, T., Wiederhold, H., and Auken, E.: Seismic results as a-priori knowledge for airborne TEM data inversion - a case study, J. Appl. Geophys., 80, 121-128, doi:10.1016/j.jappgeo.2012.02.003, 2012.

BURVAL Working Group: Buried Quaternary valleys - a geophysical approach, Z. Dtsch. Ges. Geowiss., 160, 237-247, 2009.

Christensen, N. B., Reid, J. E., and Halkjær, M.: Fast, laterally smooth inversion of airborne time-domain electromagnetic data, Near Surf. Geophys., 7, 599-612, 2009.

European Commission: Common implementation strategy for the water framework directive (2000/60/EC). Guidance document No. 24, River basin management in a changing climate, Technical Report 40, 2009.

Fountain, D.: Airborne electromagnetic systems 50 years of development, Explor. Geophys., 29, 1-11, 1998.

Frohlich, R. K. and Parke, C. D.: The electrical resistivity of the vadose zone - field study, Ground Water, 27, 525-530, 1989.

Grabowski, I.: Ableitung hydraulischer und thermischer Untergrundparameter aus elektromagnetischen Messungen am Beispiel der Insel Föhr, Diplomarbeit, Institut für Geowissenschaften der Christian-Albrechts-Universität Kiel, 2012 (in German).

Gripp, K.: Erdgeschichte von Schleswig-Holstein, Wachholz Verlag, Neumünster, 1964 (in German).

Green, T. R., Taniguchi, M., Kooi, H., Gurdak, J. J., Allen, D. M., Hiscock, K. M., Treidel, H., and Aureli, A.: Beneath the surface 
of global change: Impacts of climate change on groundwater, J. Hydrol., 405, 532-560, 2011.

Günther, T. and Müller-Petke, M.: Hydraulic properties at the North Sea island Borkum derived from joint inversion of magnetic resonance and electrical resistivity soundings, Hydrol. Earth Syst. Sci. Discuss., 9, 2797-2829, doi:10.5194/hessd-9-2797-2012, 2012.

Gürs, K.: Das Tertiär Norddeutschlands in der Stratigraphischen Tabelle von Deutschland 2002, Newsl. Stratigr., Berlin Stuttgart, 2005 (in German).

Gunnink, J. L., Bosch, J. H. A., Siemon, B., Roth, B., and Auken, E.: Combining ground-based and airborne EM through Artificial Neural Networks for modelling glacial till under saline groundwater conditions, Hydrol. Earth Syst. Sci., 16, 30613074, doi:10.5194/hess-16-3061-2012, 2012.

Holman, I. P., Allen, D. M., Cuthbert, M. O., and Goderniaux, P.: Towards best practice for assessing the impacts of climate change on groundwater, Hydrogeol. J., 20, 1-4, 2012.

Høyer, A. S., Lykke-Andersen, H., Jørgensen, F., and Auken, A.: Combined interpretation of SkyTEM and high-resolution seismic data, J. Phys. Chem. Earth, 36, 1386-1397, doi:10.1016/j.pce.2011.01.001, 2011.

Jørgensen, F. and Sandersen, P. B. E.: Buried valley mapping in Denmark: evaluating mapping method constraints and the importance of data density, Z. Dtsch. Ges. Geowiss., 160, 211-223, 2009.

Jørgensen, F., Scheer, W., Thomsen, S., Sonnenborg, T. O., Hinsby, K., Wiederhold, H., Schamper, C., Burschil, T., Roth, B., Kirsch, R., and Auken, E.: Transboundary geophysical mapping of geological elements and salinity distribution critical for the assessment of future sea water intrusion in response to sea level rise, Hydrol. Earth Syst. Sci., 16, 1845-1862, doi:10.5194/hess-161845-2012, 2012.

Klimke, J.: Erstellung eines geologisch - geophysikalischen Untergrundmodells für den Bereich des pleistozänen Quakenbrücker Beckens in Niedersachsen, Masterarbeit, Institut für Geologie der Leibniz Universität Hannover, 2012 (in German).

Koopmann, H., Gaedicke, C., and Lutz, R.: The glaciotectonic thrust-fault complex north of Heligoland, Tagungsband 70. Jahrestagung Deutsche Geophysikalische Gesellschaft, Bochum, p. 92, 2010.

Krawczyk, C. M., Polom, U., Trabs, S., and Dahm, T.: Sinkholes in the city of Hamburg - New urban shear-wave reflection seismic system enables high-resolution imaging of subrosion structures, J. Appl. Geophys., doi:10.1016/j.jappgeo.2011.02.003, 2011.

Lesmes, D. P. and Friedman, S. P.: Relationships between the electrical and hydrogeological properties of rocks and soils, in: Hydrogeophysics, edited by: Rubin, Y. and Hubbard, S. S., Springer, Dordrecht, 87-128, 2005.

Littke, R., Bayer, U., Gajewski, D., and Nelskamp, S. (Eds.): Dynamics of complex intracontinental basins - the Central European Basin System, Springer, Berlin, 2008.

LLUR: Der Untergrund von Föhr: Geologie, Grundwasser und Erdwärme, Ergebnisse des INTERREG-Projekts CLIWAT. Schriftenreihe LLUR SH - Geologie und Boden 18, 102 pp., Landesamt für Landwirtschaft, Umwelt und ländliche Räume Schleswig-Holstein, Flintbek, 2012 (in German).

Marion, D., Nur, A., Yin, H., and Han, D.: Compressional velocity and porosity in sand-clay mixtures, Geophysics, 57, 554-563,
1992.

Morawski, W.: Glaciotectonic structures of the southern Warmia region (Poland), in: The application of geophysical methods in the study of Cenozoic deposits and glaciotectonic deformations as exemplified by the southern Warmian region (Poland), edited by: Morawski, W., Prace Panstwowego Instytutu Geologicznego 180, 109-141, Warszawa, 2004 (in Polish).

Mulligan, A. E., Evans, R. L., and Lizarralde, D.: The role of paleochannels in groundwater/seawater exchange, J. Hydrol., 335, 313-329, 2007.

Nishikawa, T., Siade, A. J., Reichard, E. G., Ponti, D. J., Canales, A. G., and Johnson, T. A.:Stratigraphic controls on seawater intrusion and implications for groundwater management, 10 Dominguez Gap area of Los Angeles, California, USA, Hydrogeol. J., 17, 1699-1725, 2009.

Paine, J. G. and Minty, B. R. S.: Airborne Hydrogeophysics, in: Hydrogeophysics, edited by: Rubin, Y. and Hubbard, S. S., Springer, Dordrecht, 333-357, 2005.

Polom, U., Hansen, L., Sauvin, G., L'Heureux, J. S., Lecomte, I., and Krawczyk, C., Vanneste, M., and Longva, O.: Highresolution $\mathrm{SH}$-wave seismic reflection for characterization of onshore ground conditions in the Trondheim Harbor, Central Norway, edited by: Miller, R. D., Bradford, J. D., and Holliger, K., Advances in Near-Surface Seismology and Ground-Penetrating Radar, SEG, Tulsa, 297-312, 2010.

Polom, U., Druivenga, G., Großmann, E., Grüneberg, S., and Rode, W.: Transportabler Scherwellenvibrator, DPMA Patentschrift DE10327757B4, 26 May 2011 (in German).

Pride, S. R.: Relationships between seismic and hydrological properties, in: Hydrogeophysics, edited by: Rubin, Y. and Hubbard, S. S., Springer, Dordrecht, 253-290, 2005.

Pugin, A. J. M., Pullan, S. E., Hunter, J. A., and Oldenborger, G. A.: Hydrogeological prospecting using P- and S-wave landstreamer seismic reflection methods, Near Surf. Geophys., 7, 315-327, 2009.

Rumpel, H.-M., Binot, F., Gabriel, G., Siemon, B., Steuer, A., and Wiederhold, H.: The benefit of geophysical data for hydrogeological 3-D modelling - an example using the Cuxhaven buried valley, Z. Dtsch. Ges. Geowiss., 160, 259-269, 2009.

Seifert, D., Sonnenborg, T. O., Scharling, P., and Hinsby, K.: Impact of buried valley on groundwater vulnerability, Hydrogeol. J., 16, 659-674, doi:10.1007/s10040-007-0252-3, 2008.

Sen, P. N., Goode, P. A., and Sibbit, A.: Electrical conduction in clay bearing sandstones at low and high salinities, J. Appl. Phys., 63, 4832-4840, 1988.

Siemon, B., Steuer, A., Meyer, U., and Rehli, H.-J.: HELP-ACEH - a post-tsunami helicopter-borne groundwater project along the coasts of Aceh, northern Sumatra, Near Surf. Geophys., 5, 231 240, 2007.

Siemon, B., Christiansen, A. V., and Auken, E.: A review of helicopter-borne electromagnetic methods for groundwater exploration, Near Surf. Geophys., 7, 629-646, 2009.

Steuer, A., Siemon, B., and Auken, E.: A comparison of helicopterborne electromagnetics in frequency- and time-domain at the Cuxhaven valley in Northern Germany, J. Appl. Geophys., 67, 194-205, 2007.

Stewart, M. T.: Geophysical investigations, in: Seawater intrusion in coastal aquifers, edited by: Bear, J., Cheng, A. H.-D., Sorek, S., Ouazar, D., and Herrera, I., Kluwer Academic Publishers, 9-50, 
1999.

StUA Schleswig: Hydrogeologischer Bericht zur Bemessung von Wasserschutzgebieten für die Wasserwerke Föhr-Ost und -West des Wasserbeschaffungsverbandes Föhr, Report, Staatliches Umweltamt Schleswig, 83 pp., Schleswig, 2006 (in German).

Sulzbacher, H., Wiederhold, H., Siemon, B., Grinat, M., Igel, J., Burschil, T., Günther, T., and Hinsby, K.: Numerical modelling of climate change impacts on freshwater lenses on the North Sea Island of Borkum, Hydrol. Earth Syst. Sci. Discuss., 9, 34733525, doi:10.5194/hessd-9-3473-2012, 2012.

Sørensen, K. I. and Auken, E.: SkyTEM - A new high-resolution helicopter transient electromagnetic system, Explor. Geophys., 35, 191-199, 2004.
Viezzoli, A., Christiansen, A. V., Auken, E., and Sørensen, K.: Quasi-3-D modeling of airborne TEM data by spatially constrained inversion, Geophysics, 73, F105-F113, 2008.

Voss, C.: Editor's message: Groundwater modeling fantasies - Part 1, adrift in the details, Hydrogeol. J., 19, 1281-1284, $2011 \mathrm{a}$.

Voss, C.: Editor's message: Groundwater modeling fantasies - Part 2, down to earth, Hydrogeol. J., 19, 1455-1458, 2011 b.

Yilmaz, Ö.: Seismic data analysis: processing, inversion and interpretation of seismic data, Soc. Explor. Geophys., Tulsa, 2001. 